\title{
Reproductive biology and production of seeds and seedlings of Campomanesia pubescens (DC.) O. Berg. ${ }^{1}$
}

\author{
Sandra dos Santos Rodrigues ${ }^{2}$, Adriana de Oliveira Fidalgo ${ }^{2 *}$, \\ Cláudio José Barbedo²
}

\begin{abstract}
Pollination is a fundamental process to produce food and maintain biodiversity in natural areas, since the production of seeds is related to its efficiency. Studies can determine the influence of reproductive systems on seed and seedlings quality and, consequently, on the structure of populations, helping the management, plant breeding and preservation of species. Campomanesia pubescens (DC.) O. Berg. (guabiroba) is a Brazilian shrub, pollinated by bees and occasionally by dipterans. This work aimed at evaluating the influence of pollination and reproductive system on seed production and germination and on the seedlings quality of $C$. pubescens. Phenology and floral biology were studied, and fruits from controlled pollinations were collected, in the Mogi Guaçu Biological Reserve, São Paulo State. The germination of seeds originated from self- and cross-pollination were analyzed, as well as the development of seedlings up to 180 days after germination. Seeds from selfpollination produced seedlings with lower development than the ones from cross-pollination, and they were more susceptible to mortality in laboratory and in greenhouse.
\end{abstract}

Index terms: guabiroba, Myrtaceae, pollination, reproductive success.

\section{Biologia reprodutiva e produção de sementes e mudas de Campomanesia pubescens (DC.) O. Berg.}

\begin{abstract}
RESUMO - A polinização é um processo fundamental para produção de alimentos e para a manutenção da biodiversidade em áreas naturais, já que influencia diretamente a produção de sementes. O estudo da influência dos sistemas reprodutivos na qualidade das sementes e mudas e, consequentemente, na estrutura de populações, pode auxiliar o manejo, o melhoramento genético e a conservação de espécies. Este trabalho teve como objetivo avaliar a influência da polinização e da reprodução sobre a produção e a qualidade de sementes e mudas de Campomanesia pubescens (DC.) O. Berg (guabiroba), arbusto nativo do Brasil, polinizado por abelhas e ocasionalmente por dípteros. Estudaram-se a fenologia e a biologia floral e coletaram-se frutos, oriundos de polinizações controladas, na Reserva Biológica de Mogi Guaçu, São Paulo. A germinação e a qualidade das sementes originadas de autopolinização e de polinização cruzada foram analisadas, bem como o desenvolvimento das mudas até 180 dias. As sementes oriundas de autopolinização deram origem a plântulas com desenvolvimento inferior às de polinização cruzada e mais susceptíveis a mortalidade tanto em laboratório quanto em casa de vegetação.
\end{abstract}

Termos de indexação: guabiroba, Myrtaceae, polinização, sucesso reprodutivo.

\section{Introduction}

Cerrado is the second largest Brazilian biome covering approximately $22 \%$ of the national territory, distributed mainly in the central region of Brazil. It is also found in transitional environments with the Amazon, Atlantic Forest and Caatinga biomes (Conceição and Aragão, 2010; Costa et al., 2014). According to the Inventário da Flora Brasileira - Brazilian Flora Inventory (IBGE, 2008) the Myrtaceae is considered one of the richest families in the Cerrado biome, with 14 genera and 211 species. It has commercially exploited fruit species such as the Brazilian grapetree (Plinia cauliflora

\footnotetext{
${ }^{1}$ Submitted on 01/24/2017. Accepted for publication on 07/06/2017.

${ }^{2}$ Instituto de Botânica, Núcleo de Pesquisa em Sementes, 04301-902 - São Paulo, SP, Brasil.

*Corresponding author <aofidalgo@hotmail.com>
} 
(Mart.) Kausel), guava (Psidium guajava L.) and Brazilian cherry (Eugenia uniflora L.), as well as species with important medicinal properties and with the presence of volatile oils, demonstrating its great economic potential (Lima et al., 2006; Conceição and Aragão, 2010). In this family, there is the Campomanesia pubescens (DC) O.Berg (guabiroba), a native Brazilian shrub, which generally reaches $80 \mathrm{~cm}$ in height, and forms bushes (Silva et al., 2009). In the flowering period, it produces delicate white flowers, which last only one day and release pollen in the early hours of the morning (Almeida et al., 2000). The species is pollinated mainly by bees, some of which show buzz pollination behavior (Fidalgo and Kleinert, 2009).

The breeding system of plant species is extremely important for the management and conservation of the genetic resources and their domestication. The decline of pollinators, for a variety of reasons, damages the pollination process, representing a great biodiversity loss due to the disappearance of many forest species, as well as losses in the quality and quantity of fruits and seeds of economic interest (ImperatrizFonseca et al., 2012; Mariot et al., 2014; Giannini et al., 2015).

In the cerrado, several animal or plant species are threatened with extinction and it is estimated that $20 \%$ of the endangered or endemic species do not occur in legally protected areas (Klink and Machado, 2005). Changes in vegetation cover alter hydrology and affect the dynamics and carbon stocks in the ecosystem; this, among other reasons, has awakened the interest of various sectors of society for the conservation of the Cerrado (Klink and Machado, 2005).

The propagation of Cerrado species presents difficulties due to the reduced available knowledge about the ecological, morphological and physiological characteristics. In order to evaluate the quality of seeds, it is necessary to intensify the research of practical and effective methods (Herzog et al., 2012). Despite the research advances in the area, the published studies about C. pubescens are still scarce, mainly regarding the germination processes (Dousseau et al., 2011).

The integrated study of phenology, floral biology and pollination may allow understanding the reproductive strategies of plants and their interactions with pollinators (Otárola and Rocca, 2014). The research on the reproductive strategies of $C$. pubescens amplifies the knowledge regarding the influence of its reproductive system on the quality of seeds and seedlings; this can contribute to preserving it in its natural habitat. In addition, there is potential for the exploitation of its fruits in small farms linked to family farming (Herzog et al., 2012).

In this study we aimed to evaluate the effect of pollination and reproductive system on the quality of Camponesia pubescens seeds and seedlings. Therefore, the phenology, floral biology, pollination and breeding system of the species, as well as the effects on seed and seedling quality parameters were studied.

\section{Material and Methods}

This study was carried out between 2012 and 2013 in the "Reserva Biológica Mogi Guaçu" (RBMG) (22 ${ }^{\circ} 17^{\prime} \mathrm{S}$; $\left.47^{\circ} 03^{\prime} \mathrm{WG}\right)$, a 470 ha area located in the municipality of Mogi Guaçu, São Paulo state, Brazil. This area is limited on the south by the Mogi-Guaçu River, with altitudes between 560 and $700 \mathrm{~m}$, Cwa-Köppen climate and predominance of the Cerrado biome.

Pre-flowering buds of 12 individuals were bagged in order to evaluate the occurrence of spontaneous self-pollination and the consequences of pollinator exclusion. Newly opened flowers were submitted to manual self and cross-pollination treatments (Dafni et al., 2005). The control sample group consisted of non-bagged flowers exposed to natural pollination. The group of floral visitors was determined by observing and collecting the animals, with the help of a butterfly net, during the morning period, throughout the whole flowering of the individuals (about 60 hours of observation). The collected insects were identified in the Museum of Zoology of the University of São Paulo, where they are deposited.

The monitoring of the species phenology was carried out in order to determine the relation of the events with abiotic factors, and to describe variations in the flowering and fruiting moments that could affect the reproductive success and the availability of seeds and fruits. Monthly observations were made from January 2012 to December 2013. During each observation, the numbers of flower buds, open flowers, unripe and ripe fruits were counted (Fidalgo and Kleinert, 2009). After ripening, fruits were harvested, pulped manually and washed under running water, over sieves for seed separation.

Phenology data were separated by period, transformed into ratio, plotted in phenograms and analyzed by circular statistics (Batschelet, 1981), in order to determine the period of greatest flowering intensity of the species. The mean length of the vector " $\mathrm{r}$ " is the concentration measure (minimum $=0$, maximum $=1$ ) (Batschelet, 1981; Zar, 1999). The Rayleigh test (Zar, 1999) was used to obtain the significance of acrophases.

In order to evaluate germination, seeds from each pollination treatment were placed in a gerbox containing approximately $200 \mathrm{~mL}$ of sand and vermiculite $(1: 1)$ as a substrate, and incubated in a germination room at $25^{\circ} \mathrm{C}$ and continuous light. In the laboratory, the seeds were monitored daily and the following variables were analyzed: number of germinated seeds, having as a parameter the protrusion of a 2 $\mathrm{mm}$ root (RP); shoot emission (SE), normal seedling formation 
(NS, i.e. emission of the first two leaflets without deformed or damaged) and abnormal (AS, i.e. those deteriorated, without leaves, deformed and unable to give continuity to development). The germination test was closed on day 30 .

After the development in laboratory, seedlings that were about $2 \mathrm{~cm}$ tall and had a pair of leaflets developed in dark green were pricked to the nursery. In order to place the edlings, 1 liter polypropylene pots filled with $700 \mathrm{~mL}$ of substrate were used. At the bottom of the containers a layer of drainage stones was deposited and, on top of it, there was a substrate prepared with $50 \%$ of Red / Yellow Latosol with clayey texture and $50 \%$ of organic compound Forth ${ }^{\circledR}$.

Seedlings were kept in greenhouse $(531.46 \mu \mathrm{mol}$ photons. $\mathrm{m}^{-2} \cdot \mathrm{s}^{-1}$ ) under controlled irrigation conditions (three times a week). The variables analyzed in the greenhouse were: shoot height (h), stem diameter (SD), number of leaves (NL) and mortality. These variables were evaluated every two weeks, as well as the mortality of the seedlings.

On day 60, 90 and 180 after the beginning of the experiment, 15 seedlings per treatment were removed from the pots, washed to separate the residues from the substrate and evaluated as for the following parameters: leaf area (LA, estimated with the aid of the leaf area integrator LICOR ${ }^{\circledR}$ model LI-3100) and root, stem and leaf fresh matter. After drying them in a stove at $65{ }^{\circ} \mathrm{C}$ for 24 hours, the leaf dry matter (LDM), stem dry matter (SDM) and root dry matter (RDM) were evaluated. In addition, the shoot dry matter $(\mathrm{SDM}=\mathrm{LDM}+\mathrm{SDM})$, the total dry matter $(\mathrm{TDM}=\mathrm{SDM}$ $+\mathrm{RDM})$, the shoot/root system ratio $(\mathrm{SRR}=\mathrm{SDM} / \mathrm{RDM})$, the relation between shoot height/stem diameter (HDR) and the Dickson quality index (DQI) were calculated, using the formula DQI $=[\mathrm{TDM} /(\mathrm{HDR}+\mathrm{SRR})]$ (Dickson et al., 1960; Carneiro, 1995; Fonseca et al., 2002).

The mean values of the development parameters of the seedlings were compared per treatment through mean comparison tests, after analyzing data normality (Zar, 1999), using the SISVAR (Ferreira, 2011) statistical package. Selfpollination data on day 180 could not be tested due to sample insufficiency.

\section{Results and Discussion}

Campomanesia pubescens presented annual and mass flowering pattern. Its flowers have stamens organized in a shaving brush shape; anthesis occurred around 6:00 a.m. and lasted only a day, at the end of which they lost their petals and stamens, keeping only the pistil. Leaf flushing and fall patterns (Figure 1B) showed that this species started to lose its leaves in June and it lasted until September, with a high percentage of leaf fall in August $2012(\mathrm{r}=0.23 ; \mathrm{p}<0.05)$ and $2013(\mathrm{r}=0.16, \mathrm{p}<0.05)$. During this month a more intense dry period usually occurs, with average rainfalls below 50 $\mathrm{mm}$ and average temperatures below $20{ }^{\circ} \mathrm{C}$ (Figure 1A). Consequently, budding occurred in mid-September, both in $2012(\mathrm{r}=0.81, \mathrm{p}<0.05)$ and in $2013(\mathrm{r}=0.74, \mathrm{p}<0.05)$; the species remained green throughout most of the year.

In Figure 1C it is possible to observe that in 2012, flowering showed a well defined peak of buds $(\mathrm{r}=1.0, \mathrm{p}<0.05)$ and flowers $(\mathrm{r}=1.0, \mathrm{p}<0.05)$ in October and, consequently, a peak of fruits in November $(r=0.95, p<0.05)$, when there is usually an increase in both rainfall and temperature in the region (Figure 1A). In 2013, flowering started a month earlier, in September, with the appearance of new flower buds $(r=0.96, p<0.05)$; the flowering peak occurred in October $(\mathrm{r}=0.96 ; \mathrm{p}<0.05)$. The fruiting peak $(r=0.92 ; p<0.05)$ occurred between October
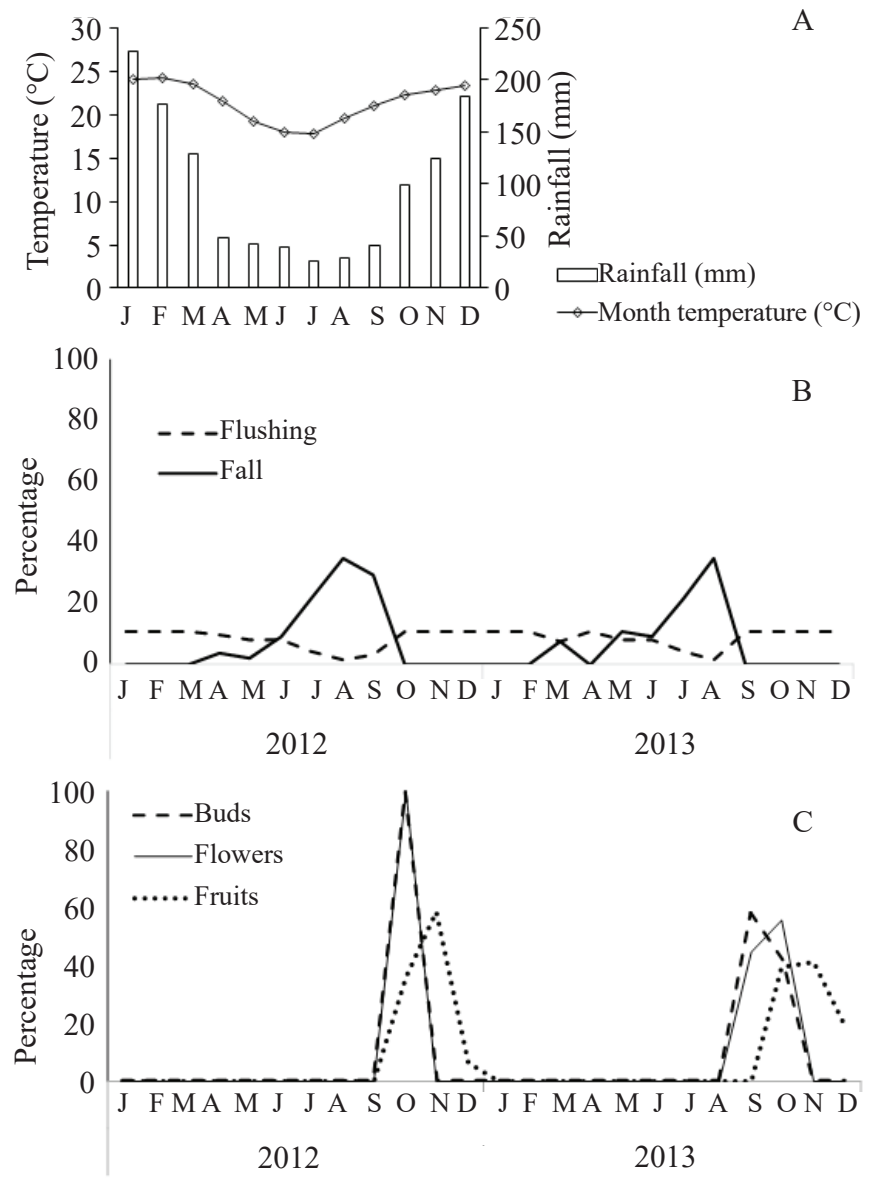

Figure 1. Phenology of Campomanesia pubescens between September 2012 and December 2013. A. Average monthly rainfall and temperature for the municipality of Mogi Guaçu, São Paulo State (Source: CEPAGRI, 2017). B. Leaf flushing and fall. C. Produced buds, flowers and fruits. 
and November of the same year.

Marked individuals were visited by a variety of insects, most frequently between 7:00 a.m. and 9:00 a.m. The main visitors were Apis mellifera Linnaeus, 1758, Scaptotrigona postica (Latreille, 1807), Melipona (Melipona) quadripasciata anthidioides Lepeletier, 1836, Trigona spinipes (Fabricius, 1793), Bombus (Fervidobombus) morio (Swederus, 1787), Oxaea flavescens Klug, 1807, Augochloropsis sp and Paratetrapedia sp, representatives of the order Hymenoptera. In addition, representatives of Coleoptera and Diptera (Syrphidae, Tachinidae) were collected.

In the spontaneous self-pollination treatment, there was no formation of fruits and seeds, whereas the presence of pollinators was mandatory for their formation. Manual crosspollination resulted in a higher success rate, followed by manual self-pollination and by the control group (Table 1). Cross-pollination showed higher results as for number of seeds per fruit, with up to seven seeds, and germination percentage.

For all treatments, germination occurred between 0 and 5 days (Figure 2A). Although the germination peak occurred at practically the same time (on day 10 ), seeds coming from the cross-pollination treatment germinated more rapidly. After this period, there was a decrease in seed germination, and the germination test ended on day 30 . There was a higher development rate of normal seedlings coming from the crosspollination treatment (34\%) in relation to the control (26\%) and to the $11 \%$ in self-pollination (Figure 2B). Moreover, seeds from cross-pollination not only anticipated the formation of seedlings but also had a greater amount of them.

The percentage of seeds that emitted shoot (SE) and developed normal seedlings (NS) were, respectively, 77.08 and $34.03 \%$ in the cross-pollination treatment, 53.27 and $26.17 \%$ in the control group and 42.16 and $10.58 \%$ in selfpollination. The time seedlings took to reach this stage was lower in self-pollination (20 days). In all treatments, $100 \%$ of the seedlings were classified as normal (NS).

During the study period, a high number of dead seedlings and plantlets were observed in the laboratory and in the greenhouse. The cross-pollination treatment had the lowest percentage of dead seedlings in all analyzed cases (Table 2).

Losses caused by mortality hindered the analysis of selfpollination data on day 180 .

The height parameter presented higher values in the cross-pollination treatment, in all evaluations, whereas the stem diameter varied among them (Table 3 ). The leaf number was similar among the treatments in the first evaluation, but

Table 1. Results obtained through controlled pollination experiments on Campomanesia pubescens.

\begin{tabular}{lccccc}
\hline \multicolumn{1}{c}{ Treatment } & Flowers $(\mathrm{n})$ & Fruits $(\mathrm{n})$ & Success $(\%)$ & Germination $(\%)$ & N. seeds/fruit $(\overline{\mathrm{X}} \pm \mathrm{sd})$ \\
\hline Spontaneous self-pollination & 40 & 0 & 0 & 0 & 0 \\
Self-pollination & 1162 & 468 & 40.3 & 78.5 & $1 \pm 0.66$ \\
Cross-pollination & 286 & 188 & 65.7 & 100.0 & $4 \pm 1.67$ \\
Control & 1695 & 301 & 17.8 & 87.7 & $2 \pm 1.02$ \\
\hline
\end{tabular}
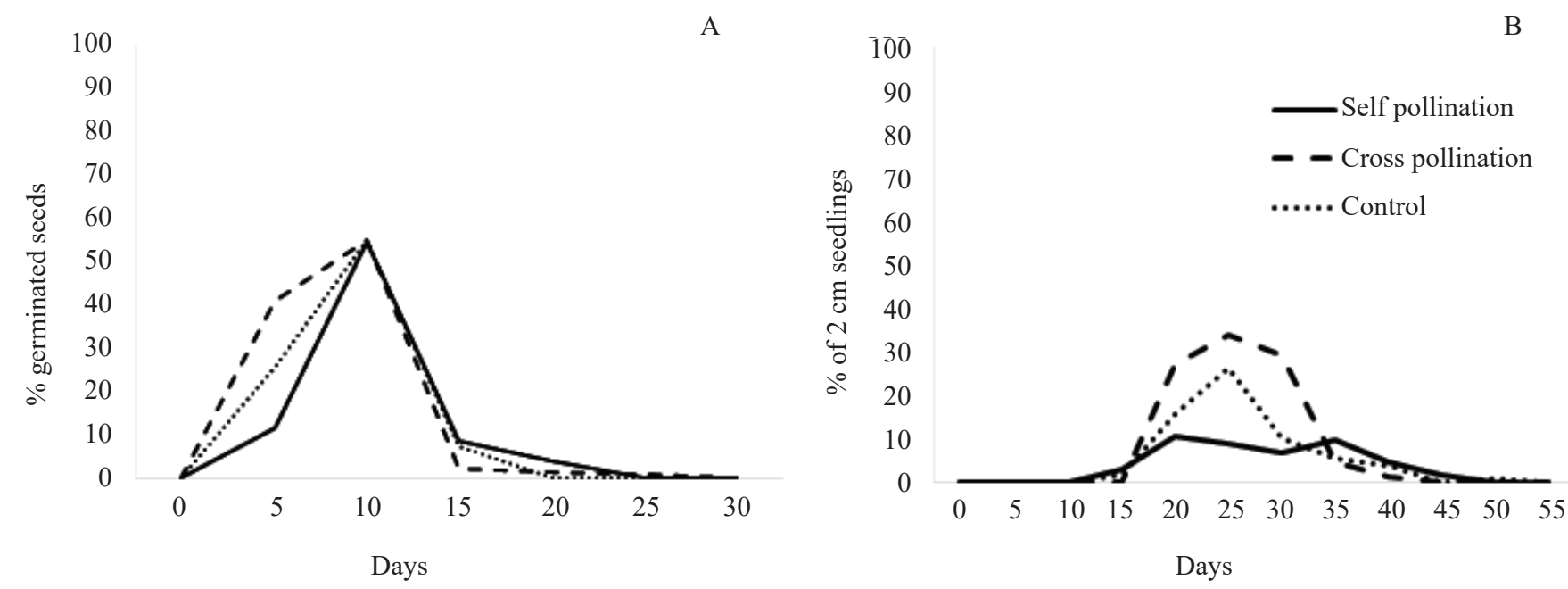

Figure 2. Temporal distribution of germination (A) and normal seedling development (B) rates for Campomanesia pubescens seeds according to the pollination treatment. 
differed in the last two, especially in the control sample and cross-pollination treatments.

Cross-pollination also presented higher averages than the other treatments in the SRR and hSDR parameters on day 60 , on day 90 days in the SDM, TDM, \%TDM, SRR and hSDR parameters and on day 180 in SDM, \%TDM, SRR and hSDR (Table 4). The Dickson quality index values (DQI) were higher for cross-pollination on day 60 and 90 . Only on day 180 the results were the same for cross-pollination and control sample (DQI $=0.72)$.

The regular annual and mass flowering and the short flower duration observed in Campomanesia pubescens are common events among Myrtaceae species (Silva and Pinheiro, 2007; Fidalgo and Kleinert, 2009). The species is pollinated by bees, pollinators of great ecological and commercial importance, responsible for the production of various foods

Table 2. Percentages of dead seedlings (DS) observed in laboratory and in greenhouse, calculated from the initial number of seeds (DS/S) and the number of normal seedlings (DS/NS).

\begin{tabular}{lcccc}
\hline \multirow{2}{*}{ Treatment } & \multicolumn{4}{c}{ \% Dead seedlings (DS) } \\
\cline { 2 - 5 } & LS/S & DS/NS & DS/S & DS/NS \\
\hline Self-pollination & 42 & 65 & 25 & 68 \\
Cross-pollination & 3 & 4 & 15 & 16 \\
Control & 31 & 55 & 11 & 68 \\
\hline
\end{tabular}

*30 days after sowing; ** 45 days after moving to a greenhouse.

Table 3. Mean of the morphological parameters evaluated, in the self-, cross-pollination and control, on day 0,90 and 180 after the beginning of greenhouse experiments. [h: height (cm); SD: stem diameter (mm); NL: number of leaves; $\mathrm{n}=45]^{*}$.

\begin{tabular}{|c|c|c|c|c|}
\hline Days after transplanting & & Self-pollination & Cross-pollination & Control \\
\hline \multirow{3}{*}{0} & $\mathrm{~h}$ & $4.92( \pm 0.68) \mathrm{a}$ & $5.27( \pm 0.97) \mathrm{a}$ & $5.19( \pm 0.96) \mathrm{a}$ \\
\hline & SD & $2.13( \pm 0.41) \mathrm{a}$ & $1.81( \pm 0.29) \mathrm{ab}$ & $1.93( \pm 0.24) b$ \\
\hline & NL & $3.6( \pm 1.82) \mathrm{a}$ & $4( \pm 1.37) \mathrm{a}$ & $3.13( \pm 0.96) \mathrm{a}$ \\
\hline \multirow{3}{*}{90} & $\mathrm{~h}$ & $4.93( \pm 1.63) \mathrm{ab}$ & $6.30( \pm 1.18) \mathrm{a}$ & $4.33( \pm 1.45) b$ \\
\hline & SD & $1.80( \pm 0.4) \mathrm{a}$ & $1.69( \pm 0.37) \mathrm{a}$ & $1.58( \pm 0.35) \mathrm{a}$ \\
\hline & NL & $5( \pm 2) \mathrm{a}$ & $8( \pm 2) a$ & $9( \pm 4) \mathrm{a}$ \\
\hline \multirow{3}{*}{180} & $\mathrm{~h}$ & $4.5^{* *}$ & $5.67( \pm 0.99) \mathrm{a}$ & $4.50( \pm 1) b$ \\
\hline & SD & 1.87 & $1.48( \pm 0.28) \mathrm{a}$ & $1.40( \pm 0.36) b$ \\
\hline & NL & 1 & $5.78( \pm 1.91) \mathrm{a}$ & $7.64( \pm 2.96) \mathrm{a}$ \\
\hline
\end{tabular}

*Different letters indicate differences between treatments within each evaluation ( 0,90 and 180 days), compared by Tukey's test at $5 \%$.**Self-pollination data on day 180 were not statistically tested, since there was a high mortality rate for this treatment.

Table 4. Mean and standard deviation of the parameters $\operatorname{SDM}(\mathrm{g}), \mathrm{TDM}(\mathrm{g}), \% \mathrm{TDM}, \mathrm{SRR}, \mathrm{hSDR}$ and DQI of Campomanesia pubescens seedlings on days 60, 90, 180. (SDM: shoot dry matter; TDM: total dry matter; SRR: shoot/root relation; hSDR: height/stem diameter relation; DQI: Dickinson quality index).*

\begin{tabular}{|c|c|c|c|c|c|c|}
\hline \multirow{2}{*}{ Treatment } & \multicolumn{6}{|c|}{60 days } \\
\hline & $\operatorname{SDM}(\mathrm{g})$ & TDM $(\mathrm{g})$ & $\%$ TDM & SRR & hSDR & DQI \\
\hline Self-pollination & $0.069 \mathrm{a} \pm 0.02$ & $0.120 \mathrm{a} \pm 0.04$ & $61.60 \pm 7.27$ & $1.74 \pm 1.35$ & $2.40 \pm 0.61$ & 1.37 \\
\hline Cross-pollination & $0.054 \mathrm{~b} \pm 0.02$ & $0.086 \mathrm{~b} \pm 0.03$ & $47.07 \pm 8.72$ & $2.05 \pm 1.15$ & $2.92 \pm 0.65$ & 1.70 \\
\hline Control & $0.059 \mathrm{a} \pm 0.02$ & $0.104 \mathrm{~b} \pm 0.04$ & $56.62 \pm 5.10$ & $1.51 \pm 0.56$ & $2.73 \pm 0.43$ & 1.33 \\
\hline \multirow{2}{*}{ Treatment } & \multicolumn{6}{|c|}{90 days } \\
\hline & $\operatorname{SDM}(\mathrm{g})$ & TDM $(\mathrm{g})$ & $\%$ TDM & SRR & hSDR & DQI \\
\hline Self-pollination & $0.074 \mathrm{~b} \pm 0.06$ & $0.160 \mathrm{~b} \pm 0.12$ & $39.01 \pm 4.92$ & $0.81 \pm 0.31$ & $2.90 \pm 1.28$ & 0.88 \\
\hline Cross-pollination & $0.108 \mathrm{a} \pm 0.04$ & $0.183 \mathrm{a} \pm 0.05$ & $45.80 \pm 7.92$ & $1.46 \pm 0.45$ & $3.82 \pm 1.15$ & 1.46 \\
\hline Control & $0.085 \mathrm{~b} \pm 0.06$ & $0.147 \mathrm{~b} \pm 0.09$ & $37.77 \pm 4.34$ & $1.30 \pm 0.34$ & $2.83 \pm 0.88$ & 1.39 \\
\hline \multirow{2}{*}{ Treatment } & \multicolumn{6}{|c|}{180 days } \\
\hline & $\operatorname{SDM}(g)$ & TDM $(\mathrm{g})$ & $\%$ TDM & SRR & hSDR & DQI \\
\hline Self-pollination** & 0.015 & 0.044 & 37.29 & 0.52 & 2.41 & 0.52 \\
\hline Cross-pollination & $0.072 \mathrm{a} \pm 0.03$ & $0.175 \mathrm{a} \pm 0.07$ & $53.73 \pm 5.77$ & $0.74 \pm 0.27$ & $3.92 \pm 0.72$ & 0.72 \\
\hline Control & $0.077 \mathrm{a} \pm 0.04$ & $0.190 \mathrm{a} \pm 0.12$ & $49.73 \pm 3.55$ & $0.66 \pm 0.36$ & $3.35 \pm 0.75$ & 0.72 \\
\hline
\end{tabular}

*Different letters indicate differences between treatments within each evaluation ( 0,90 and 180 days), compared by Tukey's test at $5 \%$.**Self-pollination data on day 180 were not statistically tested, since there was a high mortality rate for this treatment. 
(Gallai et al., 2008). Variations in the accumulated rainfall at the beginning of the rainy season from one year to the next may justify the difference observed at the beginning of the reproductive period between 2012 and 2013, since rainfall increasing stimulate budding and the consequent flowering in species from the Myrtaceae family (Gressler et al., 2006; Fidalgo and Kleinert, 2009). The studied species presented budding peaks in the same period during which humidity increased in the study area, followed by the peaks of bud, flower and fruit formation.

C. pubescens is a facultative xenogamous species, with higher fruit formation by cross-pollination, and requires pollinating agents to guarantee its fruiting; this supports the data obtained by Torezan-Silingardi and Del-Claro (1998). C. pubescens can be inserted in the "pollen-flower" group, because it only offers this resource to floral visitors. According to Vogel (1978) apud Carvalho and Oliveira (2003), this type of flowers must have been under pressure to limit bee access to pollen, thus requiring more efficient animals during the collection of the resource.

As for the observed floral visitors, bees were the most abundant in the study area, and among them, the Africanized Apis melifera. Although this species is very economically important in the production of honey and pollination of cultivars, it does not act as an effective pollinator for $C$. pubescens, collecting only grains dispersed in the flowers, thus being classified as 'pollen thief' (sensu Inouye, 1980). Some bee species show buzzing behavior and are more efficient than others in collecting pollen. Authors have described it as the most effective behavior for the pollination of species from the Myrtaceae family (Gressler et al., 2006; Fidalgo and Kleinert, 2009). Bombus morio, Melipona quadrifasciata anthidioides, Oxaea flavescens and Augochloropsis sp., perform pollination by vibration, but Augochloropsis sp. individuals are small, carry less pollen and touch the species stigma only occasionally. Syrphidae, Tachinidae and Coleoptera individuals were also observed; they are specialized in feeding on pollen and may act as both pollinators and resource thieves (Larson et al., 2001; Fidalgo and Kleinert, 2009).

Campomanesia pubescens seems to have adapted to the buzz pollination performed by bees that were present in the study area. However, the reduced reproductive success rate observed in the control sample group seems to indicate the occurrence of pollen limitation and/or reduction in the availability of efficient pollinators in the region.

Among the factors altering the quantity and quality of the pollen available to plants that require animal vectors, there is the presence of efficient and frequent pollinators in the occurrence area (Wilson and Thomson, 1991; Kasagi and Kudo, 2003). According to Nascimento et al. (2012), an effective pollination contributes to the production of good quality seed. The quantity and quality of the pollen that reaches the stigma can be one of the limiting factors for the production of quality fruits, and the greater contribution of the pollen deposited during manual pollination increases even more the chance of having fruits with a greater quantity of viable seeds, maximizing the chances of greater reproductive success (Ashman et al., 2004). The higher number of seeds per fruit in cross-pollination can therefore be explained by the large amount of pollen deposited in the stigma during manual pollination. Alves and Freitas (2007) also found similar results with another species from the family, obtaining a larger number of seeds from the same treatment.

Seeds from self-pollination have a delayed germination, formation and development of normal seedlings, as well as high mortality rates. The latter may be related to the amount of homozygotes in the population, which may lead to inbreeding depression through the expression of deleterious genes in homozygousness (Johnston and Schoen, 1996; Santos et al., 2010). Recessive genes may remain hidden in heterozygous populations; when the number of homozygotes increases in inbred populations, a greater number of recessive genes may occur, and an increase in deleterious characteristics begins to appear, thus causing vigor loss (Allard, 1971; Santos et al., 2010). There are works suggesting that self-pollination causes a low seed formation rate compared to cross-pollination; a high number of abortions, deformities and mutations occurs in plantlets and seedlings from several species (Kageyama and Piña-Rodrigues, 1993; Santos Júnior et al., 2013).

During the evaluated period, seedlings from the crosspollination treatment grew faster than the ones from other treatments in two important parameters, height and stem diameter (SD). However, none of them reached the minimum size required by the market, that is, $3 \mathrm{~mm}$ of $\mathrm{SD}$ and 30 to 35 cm of height, as proposed by Carneiro (1995).

In this work, three parameters considered important in order to evaluate the quality of seedlings were calculated: hSDR, one of the most important morphological aspects to estimate seedling growth in definitive planting on the field (Carneiro, 1995); SRR, which considers the balance of biomass distribution, and DQI, which considers in its calculation strength (HDR) and SRR (Caldeira et al., 2012). According to the results obtained in this work, seedlings from manual cross-pollination would have better quality because they present a better performance in all these parameters.

Conservation of the Cerrado biome should include, as well as the delimitation of protected areas, actions to ensure the presence of key species that perform ecological functions, such as pollination and dispersion, which are essential to 
preserve plant populations and their genetic diversity. In this work, the importance of cross-pollination was highlighted, not only to guarantee a minimum necessary amount for the propagation of the species, but also for seed vigor and quality.

\section{Conclusions}

Seeds coming from self-pollination originate seedlings with lower development than the ones from cross-pollination, and are more susceptible to mortality both in laboratory and greenhouse. Thus, pollination and reproductive processes (quality, quantity and origin of the available pollen) affect the quality of seeds and seedlings produced by Campomanesia pubescens.

\section{Acknowledgements}

The authors are grateful to MSc Lilian M. Asperti for her help in conducting the greenhouse experiment and the quality evaluation of the seedlings; to Dr. Kelli Ramos for the identification of the entomological material; to the Reserva Biológica de Mogi Guaçu for allowing the collections; to Mr. Edson Pires for the support with field experiments and CNPq for the productivity scholarship of C.J. Barbedo.

\section{References}

ALLARD, R.W. Principios do melhoramento genético das plantas. São Paulo: Edgard Blücher, 1971. 381p.

ALMEIDA, F.O.J.M.; NAVES, V.R.; XIMENES, A.P. Influência das abelhas (Apis mellifera) na polinização da gabiroba (Campomanesia spp.). Pesquisa Agropecuaria Tropical, v.30, n.2, p.25-28, 2000. http://www.revistas.ufg.br/pat/article/view/2581/2760

ALVES, J.E.; FREITAS, B.M. Requerimentos de polinização da goiabeira. Ciência Rural, v.37, n.5, p.1281-1286, 2007. http://www. scielo.br/pdf/cr/v37n5/a10v37n5.pdf

ASHMAN, T.L; KNIGHT, T.M.; STEETS, J.A.; AMARASEKARE, P.; BURD, M.; CAMPBELL, D.R.; DUDASH, M.R.; JOHNSTON, M.O.; MAZER, S.J.; MITCHELL, R.J.; MORGAN, M.T.; WILSON, W.G. Pollen limitation of plant reproduction: ecological and evolutionary causes and consequences. Ecology, v.85, n.9, p.24082421, 2004. http://onlinelibrary.wiley.com/doi/10.1890/03-8024/full

BATSCHELET, E. Circular statistics in biology. London: Academic Press. 1981. 371p.

CALDEIRA, M.V.W.; DELARMELINA, W.M.; LÜBE, S.G.; GOMES, D.R.; GONÇALVES, E.O.; ALVES, A.F. Biossólido na composição de substrato para a produção de mudas de Tectona grandis. Floresta, v.42, n.1, p.77-84, 2012. http://revistas.ufpr.br/ floresta/article/view/26302/17503
CARNEIRO, J.G.A. Produção e controle de qualidade de mudas florestais. Universidade Federal do Paraná. Fundação de Pesquisas Florestais do Paraná, Curitiba. 1995. 451p.

CARVALHO, D.A.; OLIVEIRA, P.E. Biologia reprodutiva e polinização de Senna sylvestris (Vell.) H.S. Irwin \& Barneby (Fabaceae, Caesalpinioideae). Revista Brasileira de Botânica, v.26, n.3, p.319-328, 2003. http://dx.doi.org/10.1590/S010084042003000300005

CEPAGRI. Clima dos municípios paulistas. http://www.cpa.unicamp. br/outras-informacoes/clima-dos-municipios-paulistas.html. Accessed on : May.19 $19^{\text {th }}, 2017$.

CONCEIÇÃO, G.M.; ARAGÃO, J.G. Diversidade e importância econômica das Myrtaceae do Cerrado, Parque Estadual do Mirador, Maranhão. Scientia Plena, v.6, n.7, p.1-8, 2010. https://www. scientiaplena.org.br/sp/article/view/51/38

COSTA, F.O.; LIMA, D.C.R.; SILVA, L.G.S. Biologia reprodutiva de Vatairea macrocarpa (BENTH.) Ducke (Fabaceae-Faboideae) em uma área de cerrado no município de Chapadinha, MA, Brasil. Heringeriana, v.8, n.1, p.1-19, 2014. http://portalinseer.ibict.br/ index.php/heringeriana/article/view/92/88

DAFNI, A.; KEVAN, P.G.; HUSBAND, B.C. Practical Pollination Biology. Environquest, Ontario. 2005. 590p.

DICKSON, A.; LEAF, A.L.; HOSNER, J.F. Quality appraisal of white spruce and white pine seedling stock in nurseries. Forestry Chronicle, v.36, p.10-13, 1960. http://pubs.cif-ifc.org/doi/pdf/10.5558/tfc36010-1

DOUSSEAU, S.; ALVARENGA, A.A.; GUIMARÃES, R.M.; LARA, T.S.; CUSTÓDIO, T.N.; CHAVES, I.S. Ecofisiologia da germinação de sementes de Campomanesia pubescens. Ciência Rural, v.41, n.8, p.1362-1368, 2011. http://www.redalyc.org/ pdf/331/33119312005.pdf

FERREIRA, D.F. Sisvar: a computer statistical analysis system. Ciência \& Agrotecnologia, v.35, n.6, p.1039-1042, 2011. http:// dx.doi.org/10.1590/S1413-70542011000600001

FIDALGO, A.O.; KLEINERT, A.M.P. Reproductive biology of six Brazilian Myrtaceae: is there a syndrome associated with buzzpollination? New Zealand Journal of Botany, v.47, n.4, p.355-365, 2009. http://dx.doi.org/10.1080/0028825x.2009.9672712

FONSECA, E.P.; VALÉRI, S.V.; MIGLIORANZA, E.; FONSECA, N.A.N.; COUTO, L. Padrão de qualidade de mudas de Trema micrantha (L.) Blume, produzidas sob diferentes períodos de sombreamento. Revista Árvore, v.26, n.4, p.515-523, 2002. http:// www.scielo.br/pdf/rarv/v26n4/a15v26n4.pdf

GALlAI, N.; SALLES, J.M.; SETTELE, J.; VAISSIÈRE, B. Economic evaluation of the vulnerability of world agriculture confronted with pollinator decline. Ecological Economics, v.68, n.3, p.810-821, 2008. https://halshs.archives-ouvertes.fr/ halshs-01293686/document

GIANNINI, T.C; CORDEIRO, G.D.; FREITAS, B.M.; SARAIVA, A.M.; IMPERATRIZ-FONSECA, V.L. The dependence of crops for pollinators and the economic value of pollination in Brazil. Journal of Economical Entomology, v.108, n.3, p.1-9, 2015. http://dx.doi. org/10.1093/jee/tov093 
GRESSLER, E.; PIZO, A.M.; MORELATO, C.P.L. Polinização e dispersão de sementes em Myrtaceae do Brasil. Revista Brasileira de Botânica, v.29, n.4, p.509-530, 2006. http://www.scielo.br/pdf/ $\mathrm{rbb} / \mathrm{v} 29 \mathrm{n} 4 / 01 . \mathrm{pdf}$

HERZOG, N.F.M.; MALAVASI, M.M.; MALAVASI, U.C. Morfometria dos frutos e germinação de sementes de Campomanesia xanthocarpa O. BERG. Ciências Agrárias, v.33, n.4, p.1359-1366, 2012. http:// DOI: 10.5433/1679-0359.2012v33n4p1359

IBGE. Instituto Brasileiro de Geografia e Estatística. Flora vascular do bioma cerrado. 2008. ftp://geoftp.ibge.gov.br/informacoes_ambientais/ biodiversidade/flora/documentos/flora_vascular_cerrado.pdf

IMPERATRIZ-FONSECA, V.L.; CANHOS, D.A.L.; ALVES, D.A.; SARAIVA, A.M. Polinizadores no Brasil: Contribuição e Perspectivas para a Biodiversidade, Uso Sustentável. Conservação e Serviços Ambientais. Ed.USP. 2012. 488 p.

INOUYE, D.W. The terminology of floral larceny. Ecology, v.61, n.5, p.1251-1253, 1980. https://www.jstor.org/stable/1936841?seq=1\#page_ scan_tab_contents

JOHNSTON, M.O.; SCHOEN, D.J. Correlated evolution of selffertilization and inbreeding depression: an experimental study of nine populations of Amsinckia (boraginaceae). Evolution, v.50, n.4, p.1478-1491, 1996. http://onlinelibrary.wiley.com/ doi/10.1111/j.1558-5646.1996.tb03921.x/epdf

KAGEYAMA, P.Y.; PIÑA-RODRIGUES, F.C.M. Fatores que afetam a produção de sementes. In AGUIAR, I.B.; PIÑA-RODRIGUES, F.C.M.; FIGLIOLIA, M.B. (eds.). Sementes Florestais Tropicais. Brasília: ABRATES, 1993. p.19-46.

KASAGI, T.; KUDO, G. Variations in bumblebee preference and pollen limitation among neighboring populations: comparisons between Phyllodoce caerulea and Phyllodoce aleutica (Ericaceae) along snowmelt gradients. American Journal of Botany, v.90, n.9, p.1321-1327, 2003. https://www.jstor.org/ stable/4124139?seq=1\#page_scan_tab_contents

KLINK, C.A.; MACHADO, R.B. A conservação do Cerrado brasileiro. Megadiversidade, v.1, n.1, p.145-155, 2005. https:// www. researchgate.net/publication/228342037_A_conservacao_do_ Cerrado_brasileiro

LARSON, B.M.H.; KEVAN, P.G.; INOUYE, D.W. Flies and flowers: taxonomic diversity of anthophiles and pollinators. The Canadian Entomologist, v.133, n.4, p.439-465, 2001. https://doi. org/10.4039/Ent133439-4

LIMA, M.E.L.; CORDEIRO, I.; YOUNG, M.C.M.; SOBRA, M.E.G.; MORENO, P.R.H. Antimicrobial activity of the essential oil from two specimens of Pimenta pseudocaryophyllus (Gomes) L. R. Landrum (Myrtaceae) native from São Paulo state - Brazil. Pharmacologyonline, v.3, p.589-593, 2006. http:// pharmacologyonline.silae.it/files/archives/2006/vol3/063.Lima.pdf
MARIOT, A.; MANTOVANI, A.; BITTENCOURT, R.; REIS, M.S. Aspectos da biologia reprodutiva de Drimys brasiliensis Miers. (Winteraceae) em floresta ombrófila mista, sul do Brasil. Ciência Florestal, v.24, n.4, p.877-888, 2014. http://www.scielo.br/pdf/cflo/ v24n4/0103-9954-cflo-24-04-00877.pdf

NASCIMENTO, W.M.; GOMES, E.M.L.; BATISTA, E.A.; FREITAS, R.A. Utilização de agentes polinizadores na produção de sementes de cenoura e pimenta doce em cultivo protegido. Horticultura Brasileira, v.30, n.3, p.494-498, 2012. http://dx.doi. org/10.1590/S0102-05362012000300023

OTÁROLA, M.F.; ROCCA, M.K. Flores no tempo: a floração como uma fase da fenologia reprodutiva. In: RECH, A.R.; AGOSTINI, K.; OLIVEIRA, P.E.; MACHADO, I.C. (orgs). Biologia da Polinização. Ceres Belchior, Rio de Janeiro, 2014. p.113-126.

SANTOS, A.P.M.; ROMERO, R.; OLIVEIRA, P.E.A.M. Biologia reprodutiva de Miconia angelana (Melastomataceae), endêmica da Serra da Canastra, Minas Gerais. Revista Brasileira de Botânica, v.33, n.2, p.333-341, 2010. http://www.scielo.br/pdf/rbb/v33n2/ a14v33n2.pdf

SANTOS JÚNIOR, A.; TOMAS, W.M.; JORGE, M.H.A.; HAY, J.D.V. Efeito do isolamento de árvores de Sterculia apetala sobre a emergência de plântulas no pantanal. Biotemas, v.26, n.4, p.61-67, 2013. http://dx.doi.org/10.5007/2175-7925.2013v26n4p61

SILVA, A.L.G.; PINHEIRO, M.C.B. Biologia floral e da polinização de quatro espécies de Eugenia L. (Myrtaceae). Acta Botanica Brasilica, v.21, n.1, p.235-247, 2007. http://www.scielo.br/pdf/abb/ v2 $1 \mathrm{n} 1 / 22$.pdf

SILVA, E. P.; VILAS BOAS, E.V.B.; RODRIGUES, L.J.; SIQUEIRA, H. H. Caracterização física, química e fisiológica de gabiroba (Campomanesia pubescens) durante o desenvolvimento. Ciência e Tecnologia de Alimentos, v.29, n.4, p.803-809, 2009. http://www.scielo.br/pdf/cta/v29n4/16.pdf

TOREZAN-SILINGARDI, M.H.; DEL-CLARO, K. Behavior of visitors and reproductive biology of Campomanesia pubescens (Myrtaceae) in cerrado vegetation. Ciência e Cultura, v.50, n.4, p.281-284, 1998. https://www.researchgate.net/ publication/236520470_Behavior_of_visitors and_reproductive biology_of_Campomanesia_pubescens_Myrtaceae_in_cerrado_vegetation

WILSON, P.S.; THOMSON, J.D. Heterogeneity among floral visitors leads to discordance between removal and deposition of pollen. Ecology, v.72, n.4, p.1503-1507, 1991. labs.eeb.utoronto.ca/ thomson/publications/Wilson $\% 20$ Thomson $\% 20$ heterogeneity $\% 20$ among\%20visitors\%201991\%20Ecology.pdf

ZAR, J.H. Bioestatistical analysis. Prentice Hall, Upper Saddle River. 1999. 664p. 